\title{
RUSKÉ STRATEGICKÉ SÍLY A AMERICKÉ JADERNÉ PRVENSTVÍ**
}

\author{
THE RUSSIAN STRATEGIC FORCES \\ AND THE AMERICAN NUCLEAR PRIMACY
}

\author{
Jaroslav $\check{S}$ VESTKA ${ }^{*}$
}

\begin{abstract}
Abstrakt
Článek analyzuje aktuální stav ruských strategických sil a představuje scénár̆ možného odzbrojujicího a zničujicího útoku strategických sil USA proti ruskému protivníkovi. Zjištuje závažnou zranitelnost ruských strategických sil a zpochybňuje přetrvávající stav vzájemně zaručeného zničení ve vztahu mezi Ruskem a USA. Přípěvek odhaluje př́činy ruské zranitelnosti v nespolehlivém systému časného varování a nedostatku operačních zkušeností.
\end{abstract}

\begin{abstract}
The article analyses the current status of the Russian strategic forces and creates a scenario of possible disarming and decapitation strike of the U.S. strategic forces on its Russian counterpart. It reveals serious vulnerability of the Russian strategic forces and disputes the continuing existence of mutually assured destruction relation between Russia and the United States. The contribution discovers causes of Russian vulnerability in the unreliable early-warning system and lack of operational experience.
\end{abstract}

\section{Klíčová slova}

Strategické síly, strategická stabilita, Rusko, USA, odzbrojující úder, MAD.

\section{Keywords}

Strategic forces, strategic stability, Russia, USA, disarming strike, MAD.

$$
* * *
$$

\section{ÚVOD}

V diskusi o protiraketové obraně nejednou zaznělo tvrzení, že ruské strategické síly si vůči Spojeným státům udržují vysoký odstrašující potenciál, který v dohledné době neohrozí ani budovaná protiraketová obrana. Tato teze se však opírá o pouhé numerické srovnání strategických jaderných arzenálů obou zemí, aniž by byla blíže zkoumána velmi komplexní otázka zranitelnosti ruských strategických sil. Nástrojem k určení zranitelnosti je vytvoření co nejrealističtějšího scénáře prvního úderu. Tento článek si proto klade za cíl zpochybnit s využitím modelového scénáře prvního úderu často nekriticky přijímané tvrzení, že mezi USA a Ruskem existují podmínky pro odstrašování založené na vzájemném zaručeném zničení.

Výrazem ,„první úder“ označuji kombinaci dekapitačního úderu, zacíleného na prvky systému velení, řízení a komunikace, a odzbrojujícího úderu, zaměřeného na zničení strategických sil.

\footnotetext{
*E-mail: 65339@mail.muni.cz

** Text je aktualizovaným výňatkem z diplomové práce Vojenská a politická reakce Evropy a Ruska na BMDS Spojených států amerických, která je veřejně přístupná na internetu.
} 


\section{STRATEGICKÉ SÍLY RUSKÉ FEDERACE}

Na začátku roku 2008 měly ruské Strategické raketové síly 452 operačních raketových nosičů mezikontinentálního doletu (intercontinental ballistic missile; ICBM), které mohly nést až 1677 jaderných hlavic. ${ }^{1}$

Tabulka 1: Strategické raketové síly Ruska 2008

\begin{tabular}{||c|c|c|c||}
\hline Raketový systém & Počet nosičù & Hlavic na nosiči & Celkem hlavic \\
\hline SS-18 (R-36MUTTCh/R-36M2) & 75 & 10 & 750 \\
\hline SS-19 (UR-100NUTTCh) & 110 & 6 & 660 \\
\hline SS-25 (Topol) & 213 & 1 & 213 \\
\hline SS-27 (Topol-M) silo & 48 & 1 & 68 \\
\hline SS-27 (Topol-M) mobilní & 6 & 1677 \\
\hline Celkem & 452 & & 6 \\
\hline
\end{tabular}

Zdroj dat: PODVIG, Pavel. Strategic Rocket Forces (on-line).

Strategické námořní síly Ruska podle oficiálních prohlášení disponovaly na počátku roku 2008 12 strategickými jadernými ponorkami vyzbrojenými balistickými raketami (ballistic missile submarine, nuclear-powered; SSBN). Celkem 172 námořních raket dlouhého doletu (submarinelaunched ballistic missile; SLBM) mohlo nést až 606 jaderných hlavic.

Tabulka 2: Strategické námořní síly Ruska 2008

\begin{tabular}{||c|c|c|c|c|c||}
\hline Typ SSBN & Počet SSBNs & Počet SLBMs & $\begin{array}{c}\text { Typ nesených } \\
\text { SLBMs }\end{array}$ & $\begin{array}{c}\text { Hlavic na jedné } \\
\text { SLBM }\end{array}$ & $\begin{array}{c}\text { Celkem } \\
\text { hlavic }\end{array}$ \\
\hline $\begin{array}{c}\text { Delta III } \\
\text { (Projekt 667BDR) }\end{array}$ & 6 & 82 & $\begin{array}{c}\text { SS-N-18 } \\
\text { (R-29R) }\end{array}$ & 3 & 246 \\
\hline $\begin{array}{c}\text { Delta IV } \\
\text { (Projekt 667BDRM) }\end{array}$ & 6 & 90 & $\begin{array}{c}\text { SS-N-23 } \\
\text { (R-29RM) }\end{array}$ & 4 & 606 \\
\hline Celkem & 12 & 172 & & & \\
\hline
\end{tabular}

Zdroj dat: PODVIG, Pavel. Strategic Fleet (on-line). 
Skutečný počet operačních plavidel byl však nižší než deklarovaných 12. V letech 2007-2008 byly vyřazovány nejméně dvě Delta III, po jedné od Pacifické a Severní flotily, celkový počet tedy nebyl 6, ale nejvíce 4 Delta III.

Je plánováno, že šest plavidel Delta IV bude provozováno i nadále a v souladu s tím procházejí modernizací, jejíž součástí je i instalace SLBMs Siněva (R-29RM) z obnovené výroby² jako náhrady za ty, jejichž životnost skončila. ${ }^{3} \mathrm{Na}$ začátku roku 2008 se z modernizace vrátilo již čtvrté plavidlo Delta IV, dvě zbývající měly být v této době v doku. ${ }^{4}$

Od roku 1996 Rusko pracuje na uvedení nové třídy strategických ponorek Borej do služby. Tyto snahy však nedošly úspěšného naplnění ani do začátku roku 2008, především kvůli nedostatku financí, potížím s konstrukcí a zpoždění vývoje nové SLBM na tuhé palivo SS-N-30 (R-30 Bulava). ${ }^{5}$ Přestože první ponorka Borej byla spuštěna na vodu v roce 2007 , její uvedení do služby i s SLBMs na palubě lze očekávat nejdříve v roce 2009.

V tabulce je zcela opomenuta ponorka Dimitrij Donský (tř̌́da Tajfun, Projekt 941), která byla stejně jako ostatní plavidla třídy Tajfun stažena ze služby poté, co skončila životnost jí nesených SLBMs R-39, a v současnosti slouží jako testovací platforma nových raket Bulava. Podle vrchního velitele námořnictva Vladimíra Masorina existují plány na přebudování všech dvaceti odpalovacích šachet ponorky pro novou raketu a její opětovné zařazení do služby. ${ }^{6}$ Tajfuny jsou bezesporu velkolepá plavidla, avšak neméně impozantní jsou i náklady na jejich provoz. Z tohoto pohledu se tedy zdá realizace plánu na podržení Dimitrije Donského ve službě nepravděpodobná za předpokladu, že nedojde k novým významným komplikacím s třídou Borej.

Tabulka 3: Strategické letectvo Ruska 2008

\begin{tabular}{||c|c|c|c|c||}
\hline Bombardér & Počet bombardérů & Typ nesené ALCM & $\begin{array}{c}\text { Nosnost } \\
\text { bombardéru }\end{array}$ & $\begin{array}{c}\text { Celkem } \\
\text { ALCMs }\end{array}$ \\
\hline \begin{tabular}{c} 
Tu-95MS6 (Bear H6) \\
\hline $\begin{array}{c}\text { Tu-95MS16 } \\
\text { (Bear H16) }\end{array}$
\end{tabular} & 32 & AS-15A Kent (Ch-55) & 6 & 192 \\
\hline Tu-160 (Blackjack) & 14 & AS-15A Kent (Ch-55) & 16 & 512 \\
\hline Celkem & 78 & AS-15B Kent-B (Ch-55SM) & 12 & 168 \\
\hline
\end{tabular}

Zdroj dat: PODVIG, Pavel. Strategic Aviation (on-line).

\section{SYSTÉM VČASNÉHO VAROVÁNÍ RUSKÉ FEDERACE}

Systém včasného varování sestává ze tří hlavních komponentů: satelitů včasného varování, radarů včasného varování a systému velení, řízení a komunikace (command, control, communications; C3).

Rusko na začátku roku 2008 provozovalo dva typy satelitů včasného varování, tvořících součást systému první generace US-KS (Oko). Systém US-KS v plném složení měl být tvořen devíti satelity na eliptické orbitě a jednoho geostacionárního satelitu. Taková konfigurace by umožňovala kontinuální sledování amerických základen ICBMs, avšak nezaznamenala by odpálení mimo území USA. ${ }^{7}$ Mnohem významnější je skutečnost, že systém US-KS pokrývá v současnosti pouze zlomek své plánované kapacity: na počátku roku 2008 pouze dva satelity na eliptické orbitě - Kosmos 2422 (vypuštěný v červenci 2006) a Kosmos 2430 (ř́ijen 2007) - a jeden geostacionární - Kosmos 
2379. Na eliptické orbitě se pohybují satelity typu 73D6 ${ }^{8}$. Každý z nich se nachází v pozici umožňující pozorování území Spojených států asi šest hodin denně. Ještě v první polovině roku 2007 byly výpadky ve sledování částečně vyrovnávány kontinuálním monitorováním Severní Ameriky satelitem 2379 novějšího typu 71Ch6, schopným detekce i proti zemskému povrchu, na geostacionární pozici nad rovníkem na $24^{\circ}$ západně, přestože ani tato data nebyla př́liš spolehlivá. V záŕí 2007 byl však satelit přesunut ještě dále od USA, na $12^{\circ}$ východně. Změna souvisí zřejmě s blížícím se koncem operačního života tohoto šest let starého satelitu. Pokud je satelit stále funkční, měl by být schopen monitorovat oblast severního Atlantiku. ${ }^{9}$ Již delší dobu je v plánu vytvoření pokročilejšího systému US-KMO, sestávajícího ze satelitů typu 71Ch6, který by byl schopen globálního pokrytí, jeho budování však zatím nebylo zahájeno a zřejmě ani nebude, protože již byl ohlášen novější systém, nazvaný EKS. Ten by měl být pravděpodobně opět tvořen geostacionárním satelitem a několika satelity na eliptické orbitě. Testování komponentů by mělo začít během dvou let. $^{10}$

Na začátku roku 2007 Rusko provozovalo sedm pozemních radarových stanic včasného varování, jedna byla ve výstavbě a pro včasné varování byl využíván i 360stupňový radar v Puškinu u Moskvy, tvořící součást moskevské protiraketové obrany.

Tabulka 4: Ruské radary včasného varování

\begin{tabular}{||c|c|c||}
\hline Radarová stanice & Typ radaru & Uvedení do provozu \\
\hline Olenegorsk & $\begin{array}{c}\text { Dněstr-M/Dněpr } \\
\text { Daugava }\end{array}$ & $1976-1978$ \\
\hline Mišelevka & dva Dněstr-M/Dněpr & $1972-1976$ \\
\hline Balchaš (Kazachstán) & dva Dněstr-M/Dněpr & $1972-1976$ \\
\hline Pečora & Darjal & 1984 \\
\hline Gabala (Ázerbajdžán) & Darjal & 2002 \\
\hline Baranoviči (Bělorusko) & Volha & 2006 \\
\hline Lechtusi & Voroněž-DM & ve výstavbě \\
\hline Armavir & Voroněž-DM & aktivní \\
\hline Puškino, Moskva (radar ABM) & Don2-N & 1985 \\
\hline
\end{tabular}

Zdroj dat: PODVIG, Pavel. Reducing the risk of accidental launch, Appendix B, s. 36-38 a PODVIG, Pavel. Early-warning System (on-line). 


\section{Obrázek 1: Ruské radary včasného varování a protiraketové obrany. (velikost radarového vějíře nemusí odpovídat skutečnému rozsahu pokrytí)}

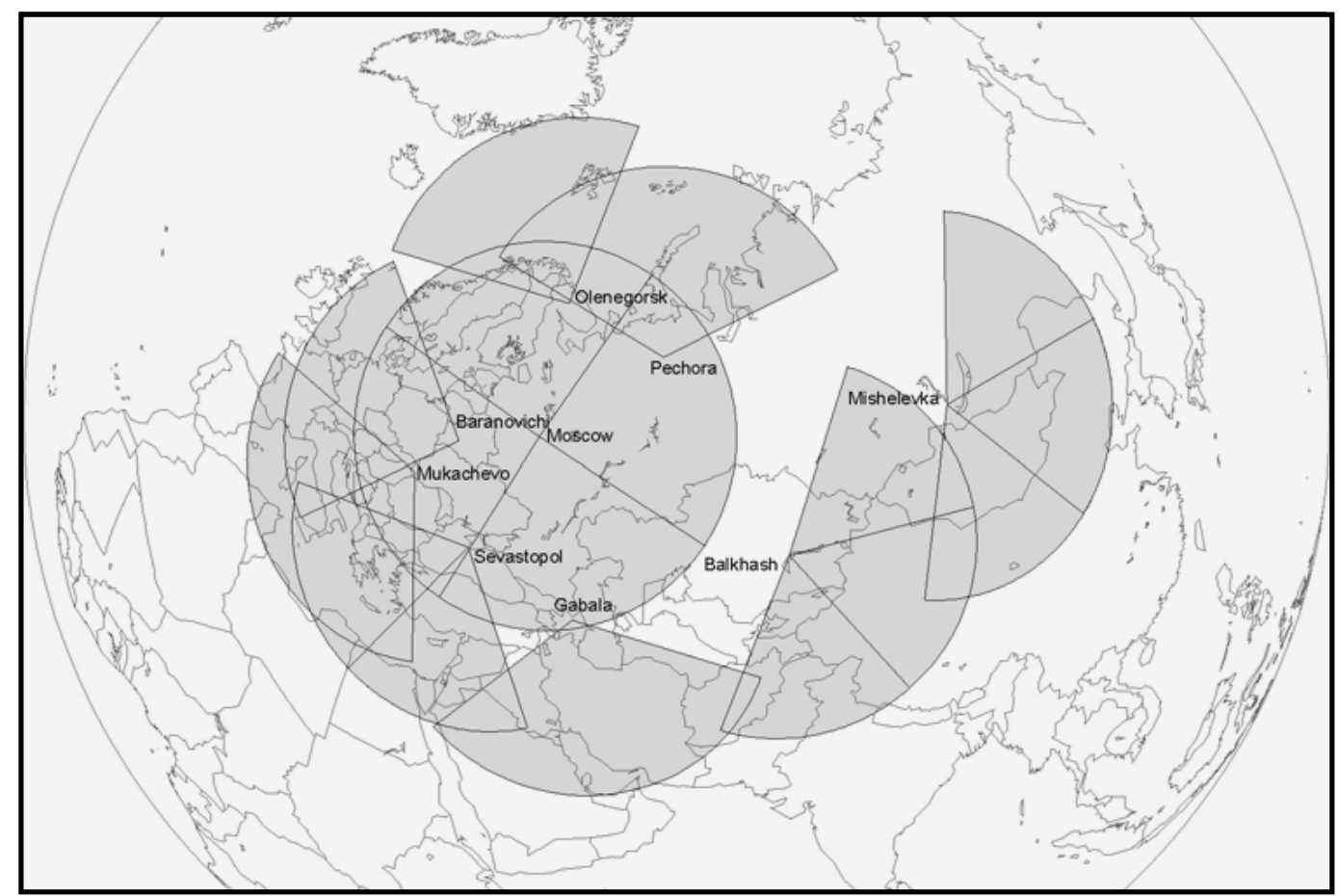

Zdroj: PODVIG, Pavel. Reducing the risk of accidental launch (on-line), Appendix B, s. 38.

Radary Darjal (Pečora a Gabala), Volha (Baranoviči) a Don2-N (Puškino) jsou velké fázové radary srovnatelné s jejich americkými protějšky. Zprovoznění radaru v Lechtusi nedaleko Petrohradu uzavřelo mezeru v radarovém pokrytí Severního moře, která se otevřela v důsledku ukončení činnosti radarové základny v Litvě. Na Obrázku 1 tento radar, vyplňující prostor mezi radarem v Baranoviči a Olenegorsku, chybí. Současně jsou na něm zobrazeny radarové stanice v Sevastopolu a Mukačevu na Ukrajině, jimi poskytovaná data však Rusko přestalo odebírat v roce 2007. Vzniklou mezeru v pokrytí na jihozápadě má zaplnit budovaná stanice v Armaviru. ${ }^{11}$ Ačkoliv současná sít' radarů včasného varování je schopna plnit své poslání, řada radarů se blíží konci svého operačního života a bude třeba je v dohledné době modernizovat. ${ }^{12}$

\section{MODELOVÝ SCÉNÁŘ PRVNÍHO ÚDERU NA RUSKO}

Schopnost zaručeného zničení protivníka po jeho prvním úderu je závislá nejen na dostupných odvetných silách, ale především na schopnosti detekovat včas, že tento první úder byl zahájen. Doby sledování raket systémy včasného varování odvodil např. Pavel Podvig ve své práci, zabývající se problémem omezování rizika neautorizovaného vypuštění balistických raket. ${ }^{13}$ Vzhledem k tomu, že satelitní systém včasného varování by měl být schopen zachytit raketu vzápětí po startu, čas letu je roven času, po který je technicky možné let sledovat satelity, což ovšem nutně neznamená, že by se tak stalo. Čas, po který by se raketa pohybovala v prostoru možné detekce pozemními radary včasného varování, je samozřejmě kratší. 
Rusko je oproti USA znevýhodněno nejen v důsledku vyspělosti amerického systému včasného varování a větší vzdáleností amerických radarů od potenciálních cílů na americkém území, ale především tradicí udržovat ruské SSBNs blízko vlastních vod a daleko od Spojených států. Pro překvapivý americký první úder je nejvhodnější nástupní lokací moře kolem Norska: detekční schopnosti ruského geostacionárního satelitu jsou v tomto prostoru slabé, takže by odpálení ani nemusel zaznamenat. Ačkoliv je oblast dostatečně pokryta radary včasného varování, blížící se hlavice by zaznamenaly pouhých asi 10 minut před dopadem na Moskvu. Zcela by mohlo chybět potvrzení údajů získávaných z radarů daty ze satelitů. Za věrohodné se přitom obvykle hlášení o útoku považuje až tehdy, pokud se shodují data přicházející ze dvou nezávislých systémů založených na odlišných fyzikálních principech: $\mathrm{z}$ radarů a ve vesmíru umístěných infračervených senzorů. ${ }^{14}$

Při americkém odzbrojujícím úderu na Rusko by samozřejmě bylo mnohem více cílů než Moskva. I pro ně však platí, že nejvýhodnější pozicí pro zahájení útoku by bylo Norské, Grónské a Barentsovo moře, popř. severní Pacifik. Vzhledem k možnosti, že starty ICBMs z území USA by byly odhaleny mnohem pravděpodobněji, by klíčovou zbraň prvního úderu tvořily SSBNs, resp. jimi nesené SLBMs.

\section{AMERICKÉ STRATEGICKÉ SÍLY V MODELOVÉM SCÉNÁŘI}

V roce 2008 americké námořnictvo provozovalo 14 SSBNs třídy 726 Ohio. Devět z nich má základnu v Bangoru (stát Washington) a 5 v Kings Bay (Georgie). Toto asymetrické rozdělení souvisí s přesvědčením, že většina potenciálních cílů je v současném strategickém prostředí lépe dosažitelná z Pacifiku (Č́ńnská lidová republika a Korejská lidově-demokratická republika) než z Atlantiku. Z devíti SSBNs v Bangoru jsou v každém okamžiku dvě na generální údržbě, což dává $\mathrm{k}$ dispozici pouze 7 operačních plavidel v Bangoru a flotilu 12 SSBNs celkově. 11 ponorek je vyzbrojeno po 24 SLBMs Trident II/D-5, jedna 24 kusy Trident I/C-4, ovšem tato ponorka bude v první polovině roku 2008 také přezbrojena Trident II/D-5. Vzhledem k tomu, že tato SSBN prochází na začátku roku 2008 modernizací, všechna akceschopná plavidla jsou vybavena Trident II/D-5. ${ }^{15}$ Ačkoliv Trident II/D-5 může nést až osm hlavic, je pravděpodobné, že plně je kapacita využita pouze na pěti plavidlech operujících z Kings Bay a jednom z Bangoru. U zbývajících SSBNs (dislokovaných v Bangoru) byl počet hlavic snížen na 6 s cílem vyhovět limitům plynoucím ze smlouvy START II. Námořnictvo se rozhodlo pro další postupné snižování počtu MIRVs na Trident II/D-5 tak, aby v roce 2012 byly naplněny závazky zakotvené ve smlouvě SORT. Během př́štích šesti let tak pravděpodobně počet hlavic připadajících na jeden Trident II/D-5 poklesne na průměrně 4. Část Trident II/D-5 nese novějšśí, vysoce přesné hlavice W88 s poloměrem kruhu, do něhož dopadne nejméně polovina hlavic (circular error probable; CEP) kolem 100 metrů a tritolovým ekvivalentem 475 kt. Výsledkem této kombinace je zbraň vhodná pro odzbrojující úder na jaderné síly protivníka. USA mají aktivních 384 hlavic W88, což dává 48 raket s osmi hlavicemi na dvou plavidlech. Zbývajících 1632 hlavic na Trident II/D-5 je typu W76. Ty procházejí modernizačním programem řešícím blížící se konec operační životnosti: zmodernizované hlavice by mělo námořnictvo dostávat od září 2007. Součástí programu není zvýšení přesnosti hlavic, W76 ale získají schopnost exploze na úrovni terénu, což zvýší jejich ničivost vůči zpevněným cílům. ${ }^{16}$

Podoba hlídek strategického odstrašování provozovaných americkými SSBNs vede $\mathrm{k}$ tomu, že v každém okamžiku je na moři kolem 8 SSBNs: část z nich přímo na hlídce a zbytek bud' na cestě do vymezené oblasti, nebo zpět do domovského přístavu. Pavel Podvig ve svém scénáři odzbrojujícího úderu USA na Rusko ${ }^{17}$ počítá do sil prvního úderu 4 SSBNs, tedy ty, které jsou přímo na hlídkových pozicích. Pokud by však byl první úder připravovaný v předstihu, pozdržením SSBNs na hlídce je možné bez vyvolání podezření shromáždit nejméně 6 plavidel. ${ }^{18} \mathrm{~V}$ případě, že by se prvního úderu zúčastnily pouze 4 SSBNs, z nichž polovina by byla vybavena hlavicemi W88 a druhá 
polovina W76 (po šesti na každé SLBM), celkem by se do útoku mohlo zapojit 384 hlavic W88 a 288 W76.

\section{MODELOVÝ SCÉNÁŘ PRVNÍHO ÚDERU NA C3}

Úspěch prvního úderu předpokládá zničení široké škály cílů: od politického a vojenského vedení, přes komunikační linky a ostatní prvky infrastruktury velení a řízení, až po jaderné zbraně a jejich nosiče. Podle počtu a povahy těchto cílů lze vyčíslit nároky na počet hlavic potřebných pro úspěšný odzbrojující úder. Pavel Podvig ve svém scénáři vycházel z dokumentu americké environmentální akční skupiny Natural Resources Defense Council ${ }^{19}$ a předpokládal, že na zničení ponorek v prŕístavech by bylo třeba 30 hlavic, základen strategického letectva 19 hlavic, velitelské a řídící infrastruktury 175 hlavic, celkem tedy

200-250 hlavic na cíle jiné než ICBMs.$^{20}$ Počet hlavic potřebných pro zničení C3 se může zvýšit, jestliže by existovalo přesvědčení, že moskevský protiraketový systém je funkční a schopný zásahu útočící hlavice. Nutnost proniknout skrze protiraketovou obranu metodou zahlcení s sebou v př́ípadě nenáhodného, rozhodného útoku nese velmi negativní důsledky pro napadeného, protože výsledná devastace způsobená velkým množstvím hlavic je vysoká.

Pro zvýšení naděje na úspěch je vhodné přímý útok na jednotlivé cíle ze skupiny C3 kombinovat s využitím účinku elektromagnetického pulsu (EMP). EMP vzniká jako výsledek interakce produktů jaderné exploze uskutečněné ve velké výšce se zemskou atmosférou, ionosférou a magnetickým polem. Při styku se zemí v ní EMP navíc vyvolává elektrické proudy. Přímý efekt EMP je výsledkem elektromagnetického šoku, který ničí veškerou neodstíněnou elektroniku a elektrické přístroje. Nepřímý efekt se odvíjí od škod na systémech, jejichž součástí jsou elektrické a elektronické prvky poškozené přímým efektem. V rámci propojených prvků (např. v elektroenergetické síti) se nepřímý efekt širíí z místa působení přímého účinku kaskádovitě a rychle vyřazuje všechny propojené komponenty.

EMP vzniká při jaderné explozi ve výškách 40-400 km. Od výšky exploze se odvíjí velikost zasažené oblasti, protože EMP zasahuje všechny cíle na zemském povrchu, které jsou v dohledu. Od velikosti hlavice se odvíjí velikost indukovaných elektrických proudů, které se běžně, avšak jako mnohem slabší, objevují v souvislosti s geomagnetickými bouřemi vyvolanými slunečním větrem. Tyto proudy jsou nebezpečné především pro elektroenergetickou infrastrukturu. $\mathrm{V}$ roce 1962 byly v SSSR provedeny jaderné testy s hlavicemi o velikosti asi 300 kt přivedenými k výbuchu ve výškách 300, 150 a 60 km. Po každé explozi bylo zaznamenáno poškození nadzemního i podzemního elektrického vedení ve vzdálenosti 600 km. ${ }^{21}$

Proti některým cílům může být výhodnější užití omezenějšího elektromagnetického pulzu v oblasti výbuchu (Source Region Electro-magnetic Pulse; SREMP), který vzniká při explozi v nižších výškách (jednotky kilometrů), má mnohem menší dosah a je vhodný k útokům proti vysoce zpevněným cílům, které mohou přestát samotnou jadernou explozi. ${ }^{22}$

Cílem použití EMP v modelovém scénáři prvního úderu je vyřazení komunikačních linek a zneschopnění C3; zvýšenou pozornost by bylo třeba věnovat prostředkům komunikace s ponořenými ponorkami: rádiovým vysílačům. U těch lze díky zesilujícímu účinku antén očekávat zvýšenou citlivost na EMP. Aby bylo zabráněno možnosti nahrazení zničené vojenské komunikační infrastruktury civilní, měl by být EMP směřován i proti ní. Modelový scénář pro vyvolání EMP vyčleňuje až 8 hlavic W/88 a 6 W/76. Jejich použití na konkrétní cíle musí brát v úvahu nejen charakter samotného cíle, ale i možné dopady na všechny objekty viditelné z místa exploze, na něž bude EMP působit, tzn. především civilní satelity (u moderních vojenských lze předpokládat vysokou odolnost vůči EMP) a ostatní hlavice podílející se na prvním úderu. Využití EMP by však mohlo být vyhodnoceno jako nevhodné vzhledem k tomu, že jde o velmi komplexní fenomén, jehož negativní důsledky nemusí být pro původce útoku přijatelné nebo spolehlivě predikovatelné. 


\section{MODELOVÝ SCÉNÁŘ PRVNÍHO ÚDERU NA ICBMS}

Hlavice W88, kombinující vysokou přesnost a silnou nálož, je schopna vyvinout i ve vzdálenosti více než dvojnásobku své CEP přetlak dostatečný ke zničení ruského sila ICBM, o němž panuje přesvědčení, že je schopno snést přetlak nejvíce kolem 2000 psi. ${ }^{23}$ Při jejím použití proto není třeba používat techniku vyslání dvou hlavic na jedno silo, ačkoliv Podvig s tímto faktem kalkuluje především proto, že nepočítá se $100 \%$ spolehlivostí útočných prostředků. Neexistují však zprávy o selhání současných Trident II/D-5 v testech, které by zpochybňovaly spolehlivost balistických raket velmi blízko sto procentům.

Na začátku roku 2008 mělo Rusko v silech umístěno 233 ICBMs, v průběhu roku lze očekávat pokles na 200-210 ICBMs. I když budeme předpokládat, že bude třeba zničit o $20 \%$ více sil, než je počet ICBMs, protože nebude zcela jisté, v kterých silech se přesně tyto ICBMs nacházejí, popř. že by na část velmi pevných sil bylo třeba užít dvě hlavice, veškerou tuto sílu je schopno vyřadit 35 SLBMs Trident II/D-5 s 280 hlavicemi W88. Na další cíle, především odolné cíle ze skupiny ,velení, řízení a komunikace“, je možné ještě použít zbývajících 12 Trident II/D-5 s 96 hlavicemi W88.

Postupný růst váhy mobilních ICBMs v ruském jaderném mixu na úkor raket umístěných v silu vnáší při úvahách o odzbrojujícím úderu do centra pozornosti otázku operačních praktik mobilních ICBMs, které jsou klíčové pro schopnost přežití těchto zbraní. Ruské ICBMs jsou organizovány do pluků. Každý pluk sestává z devíti ICBMs rozdělených do tří mobilních jednotek po třech ICBMs. Každá jednotka má společné mobilní velitelství zajištujuící řízení, komunikaci a navigaci a v poli se pohybuje jako jeden operační celek nedaleko od sebe. Proto tvoří pouze jeden cíl. ${ }^{24} \mathrm{Na}$ začátku roku 2008 měly ruské strategické raketové síly celkem zhruba 25 pluků.

Devět garáží každého pluku je vždy soustředěno na jedné základně, a to nedaleko od sebe. Vzhledem k tomu, že při odzbrojujícím úderu nemusí být jisté, které garáže jsou prázdné, bylo by třeba zničit všechny. Podvig soudí, že kvůli malé odolnosti jak garáže, tak mobilní ICBM, by na každou základnu byly použity dvě hlavice. ${ }^{25}$ Díky dopředu známé poloze garáží a základen by na tento úkol bylo možné použít 60 hlavic W76 nesených 10 SLBMs Trident II/D-5.

Za normálních okolností se podle závazků zakotvených ve smlouvě START I hlídkující ICBMs pohybují pouze uvnitř vymezených oblastí, jejichž velikost nesmí přesáhnout $125000 \mathrm{~km}^{2}$. Na každou divizi, skládající se z 2-5 pluků připadá jedna taková oblast. Uvnitř těchto oblastí se ICBMs přesunují mezi pozicemi rozmístěnými poblíž zpevněných komunikací. Tyto skutečnosti usnadňují odhalení polohy satelitním sledováním a monitorováním radiové komunikace jednotky s velením. Navíc od doby zavedení mobilních ICBMs se v hlídkování téměř jistě vytvořily určité pravidelnosti, které ulehčují zjištění jejich polohy a předvídání pohybu. ${ }^{26}$

V reálných podmínkách je téměř vyloučeno provedení zcela nečekaného prvního úderu, aniž by mu předcházela nějaká krize. Právě na postupné gradaci krize jsou založeny ruské operační plány předpokládající rozptýlení mobilních ICBMs a vyplutí SSBNs. Lze předpokládat, že ani v čase krize mobilní ICBMs neopustí oblasti vymezené ve smlouvě START I, protože by to znamenalo př́ilišné vzdálení od obslužné infrastruktury. I kdyby se tak ovšem stalo, přesun by se odehrál až v určité fázi krize, kdy lze již očekávat pečlivé satelitní monitorování ICBMs opouštějících základny. Lze očekávat, že první úder by byl zahájen v okamžiku, kdy by byly známy polohy všech jednotek ICBMs.

Při zohlednění nároků na údržbu (vysoké stáří transportérů Topolů) a stř̌́dání posádek není pravděpodobné, že by Rusko bylo schopno udržovat v poli více než $2 / 3$ strategických raketových sil, tzn. 17 z 25 pluků. Těchto 17 pluků by se rozpadalo na 51 samostatných cílů tvořených 51 mobilními jednotkami.

Ačkoliv je málo pravděpodobné, že by se během zhruba hodiny od ověření polohy do dopadu hlavic změnila poloha ICBMs, s touto možností je třeba počítat. ${ }^{27}$ Podle scénáře NRDC výbuch 100 kt nálože hlavice W76 ve výšce 1250 m nad terénem vytvoří kruhovou oblast o ploše 26 km² a poloměru $2875 \mathrm{~m}$, v níž budou zničeny všechny zde se nacházející cíle o odolnosti mobilní 
ICBM. Scénář předpokládá rychlost přesunu jednotky na úrovni $20 \mathrm{~km}$ v hodině, zatímco Podvig pracuje s rychlostí $40 \mathrm{~km}$ za hodinu. ${ }^{28}$ Vezmeme-li v úvahu průměr, tzn. $30 \mathrm{~km}$ za hodinu, a čas 1 hodinu od ověření polohy do dopadu hlavic, je třeba pokrýt $30 \mathrm{~km}$ v obou směrech silnice, což by si vyžádalo 11 hlavic W76 na jednu jednotku o třech ICBMs a 561 W76 na 51 jednotek ICBMs rozmístěných mimo základny v čase krize. Při zohlednění požadavků na zničení ostatních cílů by bylo nutné vedle scénářem předpokládaných 4 SSBNs zajistit participaci ještě tř́ SSBN, tedy celkem sedmi SSBNs. Třebaže by tato varianta nabízela kvůli kratšímu času letu SLBMs, a tím i kratší době na detekci a reakci, další zvýšení pravděpodobnosti úspěchu, shromáždění takové síly by nemuselo být možné, jestliže by se úder měl uskutečnit rychle. V takovém případě by alternativu tvořily ICBMs Minuteman III.

Na začátku roku 2008 neslo 450 ICBMs Minuteman III kolem 900 hlavic tří typư ${ }^{29}$ : W62 o tritolovém ekvivalentu 170 kt s CEP 220 m, W78 o ekvivalentu 335 kt s CEP 120 m a W87 o ekvivalentu 310 kt s CEP 100 m. Hlavice W87, původem z ICBM MX/Peacekeeper, začaly být montovány na Minutemany III v roce 2006 náhradou za W62, především s cílem zvýšit bezpečnost jaderných náloží. Předpokládá se, že na každé ICBM bude pouze jedna hlavice W87. ${ }^{30}$ Plnou operační kapacitu by měly mít přezbrojené Minutemany v roce 2010, v záŕí 2007 bylo modifikováno již 47 ICBMs ${ }^{31}$ Modelový scénář s použitím hlavic W87 nepočítá a předpokládá, že ICBMs vybrané k přezbrojení stále nesou W62. Použití W87 by ovšem zvýšilo kapacity prvního úderu USA.

Hlavice W78 jsou rozmístěny v počtu 750 kusů na 300 Minuteman III, na každém po 2-3 kusech. Pro následující léta zavádění limitů smlouvy SORT lze očekávat, že USA si ponechají stávajících 450 Minuteman III a na nich 500 hlavic W78 a W87. ${ }^{32}$

Podvig uvádí, že W78 je schopna zničit cíl o odolnosti mobilní ICBM v kruhu kolem místa dopadu o poloměru $4,4 \mathrm{~km} .{ }^{33}$ Budeme-li opět uvažovat o možném přesunu ruské jednotky ICBMs rychlostí $30 \mathrm{~km}$ v hodině a o čase jedné hodiny od detekce po dopad hlavic, bude při smrtícím poloměru 4,4 km k jistému zničení třeba podél cesty, oběma směry od poslední známé pozice, vyslat 7 hlavic W78. Na 51 mobilních jednotek rozmístěných v čase krize tak vychází potřeba kolem 360 hlavic W78. Použití ICBMs namísto SLBMs by se ukázalo jako nutné nejen v případě rozptýlení velkého počtu ICBMs, ale také pokud by nebylo možné předat SSBNs na pozicích aktuální polohy ICBMs. V takové situaci by SLBMs mohly být vypáleny pouze proti cílům s dlouhodobě známou polohou. Použití ICBMs by kladlo vyšší nároky na koordinaci útoku: musel by být zahájen v době, kdy nejsou ruské satelity na eliptické orbitě schopné sledovat území USA. Sledování z pozemních radarů by zabránilo jejich zničení SLBMs v prvních minutách prvního úderu.

\section{MODELOVÝ SCÉNÁŘ PRVNÍHO ÚDERU NA STRATEGICKÉ LETECTVO}

Postupné rozvíjení krize by poskytlo čas i ruskému strategickému letectvu na vyzbrojení letadel ALCMs, nastolení vysoké pohotovosti ke vzletu a zahájení dálkových hlídek. Nicméně v modelovém scénáři by součástí příprav USA na první úder bylo rozmístění letounů F-15, F-16 a F-22, AWACS a tankovacích letadel z pozemních základen i letadlových lodí tak, aby sestřelily v dostatečné vzdálenosti od území Spojených států Tu-95 a Tu-160 i všechny AS-15A Kent a AS15B Kent-B, které by se jim podařilo vypustit. Nezanedbatelný je také fakt, že v důsledku prvního úderu na $\mathrm{C} 3$ kombinovaného s použitím EMP by se k těmto letounům jak na základnách, tak ve vzduchu neměl dostat autorizační rozkaz.

\section{MODELOVÝ SCÉNÁŘ PRVNÍHO ÚDERU NA STRATEGICKÉ NÁMOŘNICTVO}

V průběhu gradující krize by zřejmě přístavy opustila část ruské flotily SSBNs. Taková akce by ovšem byla zásadní změnou v životě ruských SSBNs, které již od začátku 90. let pomalu stár- 
nou připoutány $\mathrm{k}$ molům. Mizivý počet delších hlídek a spoléhání na schopnost zaktivovat síly během krátkého období stupňující se krize vedly postupně k zásadnímu úpadku kvality personálu strategického lod'stva. Mírný nárůst počtu hlídek probíhající od roku 2001 na tomto konstatování nic nemění, protože ukazatel stále nedosahuje ani jedné hlídky ročně na každou jaderným reaktorem poháněnou útočnou ponorku (attack submarine, nuclear-powered; SSN) a SSBN ve službě. ${ }^{34}$ S ohledem na to, že americké SSNs a jejich posádky stráví mimo přístavy nesrovnatelně více času, tato skutečnost vyvolává značné pochybnosti o bojové akceschopnosti ruské flotily SSBNs a SSNs.

Spojené státy měly na začátku roku 2008 ve službě 52 SSNs tří tříd. Třída SSN-688 Los Angeles, výsledek požadavků studené války, byla projektována především za účelem plnění dvou úkolů: jednak k ochraně svazů letadlových lodí před útoky ruských reaktorem poháněných ponorek vyzbrojených raketami s plochou dráhou letu, jednak k vyhledávání a ničení ruských SSBNs. Na začátku roku 2008 provozovala U.S. Navy 46 těchto plavidel. Třída Los Angeles je postupně vyřazována ze služby tempem 1-3 plavidla ročně, poslední ponorka by měla být vyřazena v roce 2029. ${ }^{35}$ Nástupkyní třídy Los Angeles se měla stát třída SSN-21 Seawolf, vyznačující se ještě pokročilejšími schopnostmi protiponorkového boje, včetně vylepšení pro působení pod ledovým příkrovem Severního pólu, který využívaly sovětské SSBNs jako bezpečné útočiště. Záhy po zadání zakázky v roce 1989 se však ukázala nadbytečnost podobně velkých, extrémně odhlučněných, rychlých, ale na druhou stranu nákladných SSNs, a proto byla do služby uvedena pouze tři plavidla. ${ }^{36}$ Skutečnou nástupkyní třídy Los Angeles se tak stala až třída SSN-774 Virginia. Ve srovnání s třídou Seawolf jsou tato plavidla menší, pomalejší, nesou méně výzbroje a jejich schopnosti pro operace $\mathrm{v}$ arktických podmínkách jsou slabší. Na druhou stranu získaly vyspělejší senzory a zachovaly si tichost Seawolfu, což by mělo znamenat, že, na rozdíl od starších plavidel třídy Los Angeles, v tomto parametru výrazně předstihují ruskou třídu SSN Akula. Na začátku roku 2008 provozovala U.S. Navy 3 třídy Virginia, další by měla přibývat tempem jednoho ročně až do roku 2012, kdy by se produkce měla zvýšit na dvě ponorky ročně. Dosavadní produkce nedokázala průběžně nahrazovat vyřazované SSNs třídy Los Angeles. ${ }^{37}$

Přibližně při dosažení 2/3 plánované životnosti, nyní předpokládané na 33 let, procházejí americké SSNs Los Angeles generální opravou, u starších modelů spojenou s výměnou paliva, která trvá jeden, resp. dva roky. Běžnou údržbu, vyžadující někdy až 90 dnů, vykonává posádka a pomocný př́stavní personál v přestávce mezi dvěma hlídkovými plavbami. ${ }^{38}$ Ve srovnání s SSBNs nestěžují odhad dostupnosti SSNs v určitém čase pouze výluky na údržbu, ale také rozdílné trvání hlídek a požadavky na odpočinek personálu. Pokud však SSN není v dlouhodobé opravě, v čase krize může být během 24 hodin až několika dnů povolána do služby. Z dat uvedení jednotlivých plavidel do služby lze vyvodit, že v opravě ve 2/3 životnosti se stále nachází $4-5$ plavidel. Z flotily 52 SSNs je tak dostupných 47.

Primárním úkolem amerických SSNs zůstává doprovod svazů letadlových lodí. Z jedenácti letadlových lodí je na moři v každém okamžiku nejvíce 8 . Jestliže by každý z těchto svazů vyžadoval standardní doprovod 2 SSNs, bylo by k tomu třeba 16 plavidel, všechny zřejmě třídy Los Angeles. SSNs také poskytují ochranu SSBNs: na 8 SSBNs v každém okamžiku na moři počítejme 8 SSNs. Tyto požadavky by počet dostupných SSNs snížily na 23. I kdyby 5 z nich plnilo jiné úkoly nebo by nemohlo být zařazeno do bojových operací, zbývalo by 18 SSNs pro stíhání a ničení ruské strategické flotily.

Rusové mohou pro obranu svých SSBNs použít 9 SSNs třídy Akula (Projekt 971), 1 třídy Sierra I (Projekt 945), 2 Sierra II a 3-4 Viktor III (Projekt 671). Pouze 5 SSNs tř́́dy Akula je dislokováno u Pacifické flotily, všechny ostatní u Severní. Zatímco třída Akula je srovnatelná s prvními plavidly třídy Los Angeles a třída Sierra je jejím přímým předchůdcem, který však byl opuštěn především kvůli finanční a technické náročnosti výroby titanového trupu, nahrazeného u Akuly ocelovým, třída Viktor III trpí snadnější detekovatelností. Vzhledem k tomu, že ruské SSBNs by se zřejmě rozptýlily v oblastech blízko Ruska, nelze opomíjet ani možnost zapojení konvenčně poháněných útočných ponorek (hunter-killer submarine; SSK). Na konci roku 2007 mělo Rusko u Paci- 
fické flotily 8 a u Severní 5 SSKs třídy Kylo (Projekt 636), které, ač na dieselový pohon, jsou relativně tiché a schopné protiponorkového boje. ${ }^{39}$

Jestliže by se Rusům v čase krize podařilo vyslat na moře $2 / 3$ všech svých SSBNs, SSNs i SSKs ${ }^{40}$, na začátku roku 2008 by v modelovém scénáŕi prvního úderu proti 18 americkým SSNs, podporovaným letectvem, hladinovým lod'stvem a průzkumnými prostředky mohlo stát v Barentsově moři 5 Delta III a Delta IV chráněných 7 SSNs a 3 SSKs, zatímco v Beringově, Ochotském a Japonském moři 2 Delta III podporované 3 SSNs a 5 SSKs, celkem tedy 18 amerických ponorek proti 25 ruským, méně technicky vyspělým a osazeným mnohem méně zkušenými posádkami.

Převaha USA v souboji ponorkových lod'stev je nejméně patrná ze všech střetů modelového scénáře, protože eliminaci více než 98 \% ruských SLBMs, obdobně jako u ostatních součástí triády, nelze považovat za jistou. Přesto se domnívám, že šanci na odpálení ruských SLBMs (ale i ICBMs a ALCMs) směrem blízko k nule snižuje synergie tř́ faktorů. Jednak rychlost prvního úderu a opožděnost včasného varování; při útoku SLBMs by radary včasného varování na severozápadě byly zničeny během několika málo minut, území Moskvy by SLBMs od pobřeží Norska dosáhly asi za 15 minut, přičemž varování ze satelitů by přišlo nejdř́íve $15 \mathrm{~min}$. a z pozemních radarů 11 min. před dopadem a zničením nejvyššího článku C3. ${ }^{41}$ Za druhé, vyřazení veškerého zbývajícího C3 i alternativních civilních prostředků by se odehrálo během několika desítek minut kombinací přímých úderů a EMP. Tím by měla zmizet nejenom infrastruktura pro přenos autorizačního rozkazu, ale i velení samotné. V modelovém scénáři tak není nejvyšší prioritou zničení 100 \% hlavic, nýbrž co nejrychlejší zničení nejvyššího C3 a ponechání případných přeživších strategických sil bez autorizace k odvetě. Zničení strategických sil je pouze pojistkou pro př́ípad, kdyby primární úkol nebyl vykonán dostatečně rychle anebo se $100 \%$ účinností.

Za třetí, Rusové nepovažují informace dodávané jejich systémem včasného varování za zcela věrohodné, což je výsledek několika faktorů. Ruský systém včasného varování pracuje pouze $\mathrm{s}$ částí původně plánovaných komponent. $\mathrm{V}$ pokrytí systému pozemních radarových stanic začaly být teprve v posledních letech zaplňovány mezery, které vznikly po rozpadu SSSR tím, že se sovětské stanice octly na území nově samostatných států. Na rozdíl od USA nemá Rusko stanice včasného varování ve směrech nejdůležitějších pro raketovou výměnu mezi oběma zeměmi na zahraničních základnách, ale přímo podél vlastních hranic. Už tato skutečnost determinuje opožděnou detekci př́padného útoku. Satelitní část systému včasného varování, která by tento deficit mohla omezit, je však překvapivě málo rozvinutá. Dlouhodobý úpadek kapacit včasného varování ve spojení s rozkladem postihujícím zbytek armády a dokonce i společnosti, v situaci, kdy již neexistoval ideologický nepřítel, a tudíž ani strategická potřeba spolehlivého systému včasného varování, vedl k tomu, že vojenské i politické vedení Ruska ztratilo k systému včasného varování důvěru. V čase míru je proto vysoce nepravděpodobné, že by byly ruské strategické síly použity pouze na základě výstrahy od systému včasného varování. ${ }^{42} \mathrm{~V}$ situaci krize by během několika málo chaotických minut museli učinit společné rozhodnutí prezident, ministr obrany a náčelník generálního štábu, kteří by zřejmě byli již po určitém období, stráveném v politickém a vojenském vedení Ruska, socializováni na strategickou kulturu, jejíž součástí je nedůvěra v systém včasného varování. Existuje-li předpoklad, že vydání autorizačního rozkazu schváleného všemi třemi aktéry vyžaduje 10 minut $^{43}$, bylo by v situaci modelového scénáře nutné vydat jej na základě nejasných a nejistých informací a bez času na jakoukoliv, nota bene hlubší úvahu. Lieber a Press tvrdí, že ruské velení by potřebovalo 7-13 minut na provedení technických kroků počínajících detekcí útoku a končících odpálením odvetných raket. Pokud by se útočící hlavice dostaly do detekčního pole včasného varování 15 minut před dopadem, v nejlepším případě by ruské velení mělo na rozhodnutí asi 8 minut. ${ }^{44}$

Významnou roli v úvahách americké administrativy o nadějích prvního úderu na úspěch by nepochybně sehrály i psychické vlastnosti jednotlivých konkrétních osob z nejvyššího ruského vedení, především pak odolnost vůči stresu, schopnost rychlého úsudku a akceptace rizika. 


\section{VÝSLEDKY PRVNÍHO ÚDERU PODLE MODELOVÉHO SCÉNÁŘE}

Tabulka 5: SLBMs Trident II/D-5 použité v modelovém scénáři prvního úderu USA na Rusko

\begin{tabular}{|c|c|c|c|c|}
\hline Cíl & Typ hlavice & Počet hlavic & Počet SLBMs & Využitá kapacita SSBNs \\
\hline $\begin{array}{l}\text { Velení, řízení, } \\
\text { komunikace }\end{array}$ & $\begin{array}{l}\text { W88 } \\
\text { W76 }\end{array}$ & $\begin{array}{l}96 \\
90\end{array}$ & $\begin{array}{l}12 \\
15\end{array}$ & $\begin{array}{c}0,5 \\
0,63\end{array}$ \\
\hline Základny námořnictva & W76 & 30 & 5 & 0,21 \\
\hline Základny letectva & W76 & 24 & 4 & 0,17 \\
\hline ICBMs - silo & W88 & 280 & 35 & 1,46 \\
\hline ICBMs - mobilní - garáže & W76 & 60 & 10 & 0,42 \\
\hline EMP & $\begin{array}{l}\text { W88 } \\
\text { W76 }\end{array}$ & $\begin{array}{l}8 \\
6\end{array}$ & $\begin{array}{l}1 \\
1\end{array}$ & $\begin{array}{l}0,042 \\
0,042\end{array}$ \\
\hline Celkem & & $\begin{array}{l}\text { W88: } 384 \\
\text { W76: } 210\end{array}$ & $\begin{array}{l}\text { s W88: } 48 \\
\text { s W76: } 35\end{array}$ & $\begin{array}{c}\text { s W88: } 2 \\
\text { s W76: } 1,47\end{array}$ \\
\hline
\end{tabular}

Zdroj: autor.

Tabulka 6: ICBMs Minuteman III použité v modelovém scénáři prvního úderu

\begin{tabular}{||c|c|c|c|c||}
\hline Cíl & Typ hlavice & Počet hlavic & Počet ICBMs & $\begin{array}{c}\text { Použité ICBMs/ } \\
\text { celkový počet }\end{array}$ \\
\hline ICBMs - mobilní - v poli & W78 & 360 & $120-180$ & $0,27-0,40$ \\
\hline
\end{tabular}

Zdroj: autor.

Z tabulek 5 a 6 je zřejmé, že po prvním úderu podle modelového scénáře by Spojené státy disponovaly v palebné pozici 13 Trident II/D-5 osazených po 6 W76 (78 hlavic) a dále nedotčenými 192 Trident II/D-5 na zbývajících 8 SSBNs nepodílejících se na úderu. Na

270-330 Minuteman III by bylo dostupných až 540 W78, W87 a W62. Arzenál ALCMs a gravitačních bomb strategického letectva by zůstal nepoužit. Velká rezerva destrukčního potenciálu by umožnila modifikovat modelový první úder v případě, že by se některé předpoklady scénáře ukázaly být odlišnými od skutečnosti.

Naopak na ruské straně, pokud by se naplnily předpoklady scénáře, by sice některé jaderné zbraně mohly přežít první úder, avšak neexistovaly by prostředky velení a komunikace, které by 
dovolovaly je použít. I tyto zbývající cíle by však byly zničeny v druhé vlně útoku následující během několika málo hodin po první.

Na začátku roku 2008 disponovaly ozbrojené síly USA jediným typem prostředku schopného zásahu proti útočící ICBM nebo SLBM: pozemními antiraketami. Jestliže by se v modelovém scénáři prvního úderu USA na Rusko podařilo Rusku provést odvetu, za předpokladu, že na úspěšné sestřelení jedné hlavice by byly třeba dvě obranné hlavice ${ }^{45}$ a na každou ostrou hlavici by připadaly dvě falešné, které by se nepodařilo systému protiraketové obrany odlišit, systém s 24 antiraketami by dokázal zničit celkem 4 hlavice. Pokud závěrem modelového scénáře bylo, že by pravděpodobně nedošlo k odpálení žádné ICBM ani SLBM, potom schopnost zničit 4 hlavice by dále snižovala riziko vnímané v souvislosti s rozhodnutím o zahájení prvního úderu.

\section{DEBATA O AMERICKÉM JADERNÉM PRVENSTVÍ}

V dubnu 2006 publikovali Keir A. Lieber a Daryl G. Press ve Foreign Affairs článek, v němž tvrdili, že kombinace vylepšování amerického jaderného arzenálu a setrvalého úpadku ruských strategických sil dá Spojeným státům v dohledné době schopnost prvního úderu vůči Rusku. Svoje argumenty následně rozvedli v článku v International Security z jara 2006. Autoři jsou toho názoru, že Spojené státy nyní díky koordinovanému provádění zbrojních programů dosáhly cíle, o který usilovaly během celé studené války. ${ }^{46}$ Ačkoliv myšlenku, že americké administrativy se vždy vědomě snažily o jaderné prvenství, lze zpochybnit poukazem na postoje při vyjednávání smluv o omezení zbrojení a odzbrojení, které většinou přiznávaly fakticky výhodnější postavení SSSR/Rusku ${ }^{47}$, jaderného prvenství mohly Spojené státy dosáhnout jako nezamýšleného výsledku spojení několika trendů: změny geopolitické situace, úpadku ruských strategických sil a provádění modernizačních programů zaměřených na prodloužení životnosti a spolehlivosti amerických jaderných systémů a jejich adaptaci na nově pocitované hrozby: rogue states a terorismus. Jaderné prvenství může být dokonce produktem chybné reakce na skutečné aktuální hrozby, např. modernizované W76 se schopností detonace v nulové výšce mohly být zamýšleny jako nástroj boje proti těmto hrozbám, ale v praxi mohou být tímto způsobem nepoužitelné kvůli tabuizaci praktického užití jaderných zbraní v konfliktech s nižší intenzitou než boj národa o holé přežití, zatímco pro první úder by predstavovaly významný prrínos. Proto o schopnosti provést první úder vypovídá více modelování scénářů prvního úderu než hodnocení strategických dokumentů a rétoriky administrativ. Naopak o pravděpodobnosti takového úderu modelové scénáře neříkají téměř nic; pro její posouzení jsou klíčové strategické dokumenty a vyjádření členů administrativy, jinými slovy záměry americké strany.

V rámci diskuse vyvolané Lieberem a Pressem však dochází ke směšování dvou analyticky odlišných otázek a výsledkem jsou míjející se argumenty. Lieber a Press na základě údajného zjištění existující schopnosti provést první úder vyvozují a hledají důkazy pro dlouhodobý záměr dosažení jaderného primátu. Jejich odpưrci naopak vznášejí argumenty zpochybňující vědomé úsilí administrativ o jaderný primát a na základě toho dovozují jeho neexistenci; nepřipouštějí si, že mohl vzniknout jako vedlejší produkt. Modelové scénáře Liebera a Presse, Podviga, NRDC i scénár̆ obsažený v této práci, všechny, byt' s odlišnými výchozími předpoklady, ukazují skutečnost vysoké zranitelnosti ruských strategických sil prvním úderem USA. Vedle tohoto klícového konstatování je sekundární, zda byla schopnost získána záměrně či jako vedlejší produkt jiných úmyslů a procesů. Na rozdíl od budování těchto arzenálů jsou proměny záměrů s nimi charakterizovány mnohem silnější dynamikou.

Obě strany diskuse se vyznačují snahou naroubovat novou situaci na koncepce vzájemného zaručeného zničení (mutual assured destruction; MAD) a principy studené války, které si hluboce osvojily. Pro některé autory je MAD implicitně normativním ideálem, např. v příspěvku Alexeje Arbatova padají doporučení ruské straně, aby se snažila klesající početní stavy svých jaderných hlavic promítnout do odzbrojovacího procesu, čímž vlastně žádá znovunastolení strategické parity, 
úhelného kamene MAD. Arbatov existující disproporcionalitu považuje za zdroj nestability, protože předpokládá nutnost kompenzovat početní nevýhodu zavedením velmi vysoké pohotovosti strategických sil. ${ }^{48}$ Lieber a Press zase varují před možností, že jaderná nerovnováha přiblíží svět jaderné válce, odstartuje závody ve zbrojení nebo vnese do vývoje krizí nebezpečnou dynamiku. ${ }^{49}$

Diskuse odhalila zajímavou ambivalenci v postojích Pavla Podviga. Přestože ve svém článku Reducing the risk of accidental launch, psaném v první polovině roku 2006, prokázal, mimo jiné na základě argumentace o špatném operačním stavu ruských mobilních ICBMs, že první úder USA podle jeho scénáře (satelitní vyhledání a použití několika hlavic podél trasy možného pohybu) by je všechny až na 3, 4 zničil, ve stejnou dobu v odpovědi na článek Liebera a Presse, zveřejněné na www.russianforces.org, ${ }^{50}$ tvrdí, že mobilní ICBMs, stejně jako SSBNs, „,by měly dobrou šanci přestát první úder“. Podvig v odpovědi poukazuje na to, že ruské strategické síly jsou schopny plnit očekávání vojenského a politického vedení země, což může být fakt, nicméně to neříká nic o schopnosti provést odvetu. Naopak, jím uvedená čísla potvrzují ruskou zranitelnost.

Podvig také vyčítá Lieberovi a Pressovi, že předpokládají útok uskutečněný bez ruské př́ípravy. Přitom obdobně postupoval on při vytváření scénáře prvního úderu v Reducing the risk of accidental launch, když nepředpokládal zvýšení počtu mobilních ICBMs v poli nad běžnou hlídkovou úroveň ani vyplutí více SSBNs. Je nutné souhlasit s jeho tvrzením, že strategické síly kvantitativně klesaly na straně USA zhruba stejně výrazně jako na straně Ruska, avšak autor přehlíží skutečnost, že po provedení modelového prvního úderu by Rusku zůstal mnohem menší absolutní počet nosičů (nejvýše jednotky kusů) než za studené války. Podvig také opomíjí implikace spojené s protiraketovou obranou. Zahrnutí těchto faktů a modifikace modelového scénáře provedená v tomto článku, která počítá s předehrou v podobě krize, vedou k relativizaci jeho tvrzení, že protiopatření na ruské straně mohou rychle a podstatně zvýšit nejistoty spojené s prvním úderem. Toto je gros onoho skutečného posunu od MAD; škody způsobené přeživšími ruskými strategickými silami by i v nejhorším případě byly př́liš nízké na to, aby byly „zničením“ protivníka. Zatímco Rusko schopností prvního (odzbrojující + dekapitační) úderu nedisponuje, jak konstatuje Podvig v Reducing the risk of accidental launch, Spojené státy mají v tomto směru nepopiratelný primát v tom smyslu, že mohou Rusku způsobit škody zcela nesrovnatelné s těmi, které by hrozily USA $\mathrm{v}$ odvetě. Přirozeně v modelovém scénáři nemůže být podchycena řada nejistot reálného světa. Mnohé z nich však mohou být eliminovány vojenským plánováním (útočník vybírá místo, čas i prostředky tak, aby byl ve výhodě), a proto nemohou změnit závěr modelových scénár̆u o zranitelnosti ruských jaderných sil.

První úder na Rusko by liberálně demokratické Spojené státy nemohly provést, aniž by k tomu měly zásadní důvod. Preemptivní útok, jak současná americká administrativa označuje de facto preventivní útok, by přišel v určitém stadiu krize až konfliktu (obojí se může vyvinout velmi rychle) jako snaha zabránit realizaci nějaké akutní, závažné hrozby. Velikost př́padných následků realizace hrozby je potom měrítkem, prostřednictvím kterého se pohliží na přijatelnost rizik spojených s prvním úderem. ${ }^{51} \mathrm{~V}$ důsledku toho, že ve vážném konfliktu mohou být současná rizika spojená s prvním úderem akceptovatelná, zmizela mezi USA a Ruskem strategická parita.

\section{ZÁVĚR}

Mezi Ruskem a Spojenými státy nadále neexistují podmínky pro odstrašovací vztah založený na vzájemném zaručeném zničení. Kvantitativní i kvalitativní eroze ruských strategických sil ve spojení s permanentím kvalitativním růstem amerického jaderného arzenálu vede ke zpochybnění ruské schopnosti druhého úderu. Současně, shodují-li se hypotetické scénáře prvního amerického úderu v tom, že by jej byl schopen přežít pouze zlomek strategických sil Ruska, určitou roli začínají hrát i početně relativně omezené protiraketové prostředky, nicméně přínos současné protiraketové obrany k celkové zranitelnosti je nízký. 
Modelové scénáře ukazují, že zranitelnost ruských strategických sil není způsobena nedostatečným počtem hlavic, ale operačními praktikami SSBNs a mobilních ICBMs a především nespolehlivostí včasného varování. Vzhledem k omezené možnosti Ruska rozmist'ovat pozemní radary včasného varování blízko amerického území je zřejmé, že pouze pokročilý a spolehlivý systém satelitního včasného varování nepretetržitě monitorující celý glób, společně s udržováním významné části strategických sil permanentně na hlídce, dokáže navrátit Moskvě schopnost spustit odvetný úder na základě včasného varování, tedy před dopadem jaderných hlavic prvního úderu, a tím obnovit věrohodnost odstrašování podle koncepce MAD. Toto není př́liš objevné konstatování a jako takové je zřejmě ruskému politickému a vojenskému vedení známo. Skutečnost, že Kreml neuvedl do souladu s těmito fakty svoje vize budoucí podoby strategických sil ani v době, kdy mu to finanční situace díky př́ijmům z prodeje energetických surovin umožnila, naznačuje, že nepocituje potřebu připravovat se na vojenský střet se Spojenými státy. Obě země se nacházejí v novém bezpečnostním prostředí, které umožňuje překročit reliktní studenoválečnou logiku „,počítání arzenálư“, jejímž prríkladem par excellence je výše demonstrované modelování scénářů prvního úderu. Zda se podaří jako novou logiku vztahů nastolit vzájemně výhodnou spolupráci, závisí především na postojích a ambicích ruské strany. Přijmou-li strategická studia americké jaderné prvenství jako realitu, otevírá se před nimi řada slibných výzkumných témat spojených s otázkou, na jakých základech by ve světě bez MAD měl být budován vztah mezi Ruskem a Spojenými státy, šířji Západem.

\section{PozNÁMKy}

${ }^{1}$ PODVIG, Pavel. Strategic Rocket Forces (on-line).

${ }^{2}$ Siněva je pojmenování pro mírně modernizovanou SS-N-23 (R-29RM) s novými hlavicemi a navigací.

${ }^{3}$ PODVIG, Pavel. Strategic Fleet (on-line).

${ }^{4}$ PODVIG, Pavel. Bryansk submarine is back from overhaul (on-line).

${ }^{5}$ PODVIG, Pavel. Strategic Fleet (on-line).

${ }^{6}$ SOKOV, Nikolaj. Update: Russia's Recent Test of New Submarine-launched Missile Succeeds. (on-line).

${ }^{7}$ PODVIG, Pavel. Reducing the risk of accidental launch (on-line), Appendix B, s. 33-34.

${ }^{8}$ Satelity tohoto druhu mají životnost průměrně 40 měsíců. PODVIG, Pavel. Early-warning constellation is down to two satellites (on-line).

${ }^{9}$ PODVIG, Pavel. Early-warning satellite is drifting off station, PODVIG, Pavel. Early-warning System a PODVIG, Pavel. Launch of Cosmos-2430 early-warning satellite (on-line).

${ }^{10}$ PODVIG, Pavel. Russia is working on new early-warning satellites (on-line).

${ }^{11}$ PODVIG, Pavel. Reducing the risk of accidental alunch, Appendix B, s. 36-38 a PODVIG, Pavel. Updated map of early-warning radar coverage (on-line).

${ }^{12}$ PODVIG, Pavel. Reducing the risk of accidental launch (on-line), Appendix B, s. 36-38.

${ }^{13}$ PODVIG, Pavel. Reducing the risk of accidental launch (on-line).

${ }^{14}$ Tamtéž, s. 10-12.

${ }^{15}$ Podle Amy Woolfové se tato poslední SSBN vrátila do služby s Trident II/D-5 už v roce 2007. WOOLF, Amy. U.S. Strategic Nuclear Forces: Background, Developments, and Issues. (on-line), s. 16.

${ }^{16}$ WOOLF, Amy. U.S. Strategic Nuclear Forces: Background, Developments, and Issues. (on-line), s. 15-19 a NORRIS, Robert, KRISTENSEN, Hans. U.S. Nuclear forces, 2007, s. 80-81.

${ }^{17}$ PODVIG, Pavel. Reducing the risk of accidental launch, Appendix B (on-line), s.17-19.

${ }^{18}$ Lieber a Press ve svém scénáři předpokládají možnost zapojit do útoku až 8 ze 14 SSBNs, které pokládali za aktivní. Blíže: LIEBER, Keir A., PRESS, Daryl G. The End of Mad? The Nuclear Dimension of U.S. Primacy. s. $15-16$.

${ }^{19}$ Natural Resources Defense Council : The U.S. Nuclear War Plan: A Time for Change (on-line).

${ }^{20}$ PODVIG, Pavel. Reducing the risk of accidental launch (on-line), s. 21-28.

${ }^{21}$ Commission to Assess the Threat to the United States from Electromagnetic Pulse (EMP) Attack: Report.

Volume I: Executive Report 2004, s. 1-4, 17-18 (on-line).

${ }^{22}$ Global Security: Nuclear Weapon EMP Effects (on-line). 
${ }^{23}$ PODVIG, Pavel. Reducing the risk of accidental launch (on-line), s. 22-23.

${ }^{24}$ Tamtéž, s. 24-27.

${ }^{25}$ Tamtéž, s. 24-27.

${ }^{26}$ Tamtéž, s. $24-27$.

${ }^{27}$ Tamtéž, s. $24-27$.

${ }^{28}$ Tamtéž, s. 26 a Natural Resources Defense Council : The U.S. Nuclear War Plan: A Time for Change (online), s. 54.

${ }^{29}$ Přesnější určení počtu hlavic není možné kvůli probíhajícímu přezbrojování.

${ }^{30}$ NORRIS, Robert, KRISTENSEN, Hans. U.S. Nuclear forces, 2007 (on-line), s. 79-80 a PODVIG, Pavel. Reducing the risk of accidental launch (on-line), Appendix A, s. 17-28.

${ }^{31}$ WOOLF, Amy. U.S. Strategic Nuclear Forces: Background, Developments, and Issues (on-line), s. 14.

${ }^{32}$ NORRIS, Robert, KRISTENSEN, Hans. U.S. Nuclear forces, 2007 (on-line), s. 79-80 a PODVIG, Pavel. Reducing the risk of accidental launch (on-line), Appendix A, s. 17-28,.

${ }^{33}$ PODVIG, Pavel. Reducing the risk of accidental launch (on-line), Appendix A, s. 17-28.

${ }^{34}$ KRISTENSEN, Hans. Russian Nuclear Submarine Patrols. (on-line).

${ }^{35}$ Global Security: SSN-688 Los Angeles-class (on-line).

${ }^{36}$ Global Security: SSN-21 Seawolf (on-line).

${ }^{37}$ Global Security: $S S N-774$ Virginia (on-line).

${ }^{38}$ Global Security: SSN-688 Los Angeles-class (on-line).

${ }^{39}$ Russian Military Analysis: Russian Navy: Submarines: SSN (on-line).

40 Jedná se o nadhodnocený předpoklad: na začátku roku 2008 byly (nejméně) 2 z 12 SSBNs vyřazovány a další 2 na generální opravě, což samo o sobě dává $1 / 3$ ruských SSBNs.

${ }^{41}$ PODVIG, Pavel. Reducing the risk of accidental launch (on-line), s. 11.

${ }^{42}$ Tamtéž, s. 12-14.

${ }^{43}$ Global Security: Strategic Command and Control (on-line).

${ }^{44}$ LIEBER, Keir A., PRESS, Daryl G. The End of Mad? The Nuclear Dimension of U.S. Primacy, s. 21-22.

${ }^{45}$ Pokud by při útoku 5 hlavicemi byly na každou z nich použity 2 obranné hlavice, s $96 \%$ pravděpodobností by byly všechny útočící hlavice zastaveny za předpokladu, že pravděpodobnost zásahu útočící hlavice obrannou hlavicí by byla $91 \%$. Gronlund, Lisbeth, Wright, David C., Lewis, George N., Coyle III, Philip E.: Technical Realities. An Analysis of the 2004 Deployment of a U.S. National Missile Defense System (on-line text), tab. 4, s. 43.

${ }^{46}$ LIEBER, Keir A., PRESS, Daryl G. The End of Mad? The Nuclear Dimension of U.S. Primacy. a LIEBER, Keir A., PRESS, Daryl G. The Rise of U.S. Nuclear Primacy.

${ }^{47}$ Pro další důvody viz: FLORY, Peter C.W. in: FLORY, Peter, et al. Nuclear Exchange: Does Washington Really Have (or Want) Nuclear Primacy?

${ }^{48}$ ARBATOV, Alexei In: FLORY, Peter, et al. Nuclear Exchange: Does Washington Really Have (or Want) Nuclear Primacy?

${ }^{49}$ LIEBER, Keir A., PRESS, Daryl G. The End of Mad? The Nuclear Dimension of U.S. Primacy, s. 31-32.

${ }^{50}$ PODVIG, Pavel. Speaking of nuclear primacy (on-line).

${ }^{51}$ Hypotetickou situací, určenou výhradně pro demonstrování této myšlenky, by byla např̀. zásadní vnitropolitická destabilizace v Rusku spojená $s$ nástupem režimu agresivně vystupujícího vůči USA nebo NATO, provádějícím expanzionistické zahraničněpolitické kroky spojené s mobilizací vojenských zdrojů, nebo dokonce ozbrojenými střety.

\section{LITERATURA}

\section{Články}

[1] FLORY, Peter, et al. Nuclear Exchange: Does Washington Really Have (or Want) Nuclear Primacy? Foreign Affairs. September/October 2006, vol. 85, no. 5.

[2] LIEBER, Keir A., PRESS, Daryl G. The End of Mad? The Nuclear Dimension of U.S. Primacy. International Security. Spring 2006, Vol.30, No. 4. 
[3] LIEBER, Keir A., PRESS, Daryl G. The Rise of U.S. Nuclear Primacy. Foreign Affairs. March/April 2006, Vol 85, No.3.

\section{Internetové zdroje}

[4] Commission to Assess the Threat to the United States from Electromagnetic Pulse (EMP) Attack: Report. Volume I: Executive Report 2004 [online]. 2004 [cit. 2008-05-29]. Dostupný z WWW: <http://missilethreat.com/repository/doclib/20040000-EMPcomm-empthreat.pdf>.

[5] Global Security: Nuclear Weapon EMP Effects [online]. c2000-2008 [cit. 2008-05-27]. Dostupný z WWW: <http://www.globalsecurity.org/wmd/intro/emp.htm>.

[6] Global Security: SSN-21 Seawolf [online]. c2000-2008 [cit. 2008-05-29]. Dostupný z WWW: <http://www.globalsecurity.org/military/systems/ship/ssn-21.htm>.

[7] Global Security: SSN-688 Los Angeles-class [online]. c2000-2008 [cit. 2008-05-29]. Dostupný z WWW: <http://www.globalsecurity.org/military/systems/ship/ssn-688ero.htm>.

[8] Global Security: SSN-774 Virginia [online]. c2000-2008 [cit. 2008-05-29]. Dostupný z WWW: <http://www.globalsecurity.org/military/systems/ship/ssn-774-program.htm>.

[9] Global Security: Strategic Command and Control [online]. c2000-2008 [cit. 2008-05-29]. Dostupný z WWW: <http://www.globalsecurity.org/wmd/world/russia/c3i.htm>.

[10] GRONLUND, Lisbeth, et al. Technical Realities. An Analysis of the 2004 Deployment of a U.S. National Missile Defense System.. Union of Concerned Scientists [online]. 2004 [cit. 2008-05-29].

Dostupný

$\mathrm{Z}$

WWW:

$<$ http://www.ucsusa.org/global_security/missile_defense/technical-realities-nationalmissile-defense-deployment-in-2004.html> .

[11] KRISTENSEN, Hans. Russian Nuclear Submarine Patrols. The Nuclear Information Project [online]. 2007 [cit. 2008-05-29]. Dostupný <http://www.nukestrat.com/russia/subpatrols.htm>.

[12] NORRIS, Robert, KRISTENSEN, Hans. U.S. Nuclear forces, 2007. Bulletin of the Atomic Scientists [online]. 2007, no. January/February [cit. 2008-05-29], s. 79-82. Dostupný z WWW:

<http://thebulletin.metapress.com/content/j07186442060/?sortorder=asc\&p_o=20>.

[13] Natural Resources Defense Council : The U.S. Nuclear War Plan: A Time for Change [online]. 2001 [cit. 2008-05-29]. Dostupný z <http://www.nrdc.org/nuclear/warplan/index.asp>.

[14] PODVIG, Pavel. Bryansk submarine is back from overhaul. Russian Strategic Nuclear Forces [online]. 2008 [cit. 2008-05-27]. Dostupný z WWW: <http://russianforces.org/blog/2008/01/bryansk_submarine_is_back_from.shtml>.

[15] PODVIG, Pavel. Early-warning constellation is down to two satellites. Russian Strategic Nuclear Forces [online]. 2007 [cit. 2008-05-27]. Dostupný z WWW: <http://russianforces.org/blog/2007/04/earlywarning_constellation_is.shtml>.

[16] PODVIG, Pavel. Early-warning satellite is drifting off station. Russian Strategic Nuclear Forces [online]. 2007 [cit. 2008-05-27]. Dostupný z WWW: <http://russianforces.org/blog/2007/09/earlywarning_satellite_is_drif.shtml>.

[17] PODVIG, Pavel. Early-warning System. Russian Strategic Nuclear Forces [online]. 2007 [cit. 2008-05-27]. Dostupný z WWW: <http://russianforces.org/sprn/>. 
[18] PODVIG, Pavel. Launch of Cosmos-2430 early-warning satellite. Russian Strategic Nuclear Forces [online]. 2007 [cit. 2008-05-27]. Dostupný z WW: <http://russianforces.org/blog/2007/10/launch_of_cosmos2430_earlywarn.shtml>.

[19] PODVIG, Pavel. Reducing the risk of accidental launch. Science \& Global Security [online]. 2006, vol. 14, no. 2-3 [cit. 2008-05-27]. Dostupný z WWW: <http://russianforces.org/podvig/eng/publications/20061000sgs.shtml>.

[20] PODVIG, Pavel. Russia is working on new early-warning satellites. Russian Strategic Nuclear Forces [online]. 2007 [cit. 2008-05-29]. Dostupný z WWW: <http://russianforces.org/blog/2007/08/russia_is_working_on_new_early.shtml>.

[21] PODVIG, Pavel. Strategic Aviation. Russian Strategic Nuclear Forces [online]. 2008 [cit. 2008-05-29]. Dostupný z WWW: <http://russianforces.org/aviation/>.

[22] PODVIG, Pavel. Strategic Fleet. Russian Strategic Nuclear Forces [online]. 2008 [cit. 2008-05-29]. Dostupný z WWW: <http://russianforces.org/navy/>.

[23] PODVIG, Pavel. Strategic Rocket Forces. Russian Strategic Nuclear Forces [online]. 2008 [cit. 2008-05-29]. Dostupný z WWW: < http://russianforces.org/missiles/>.

[24] PODVIG, Pavel. Updated map of early-warning radar coverage. Russian Strategic Nuclear Forces [online]. 2007 [cit. 2008-05-29]. Dostupný z WWW: <http://russianforces.org/blog/2007/07/updated_map_of_earlywarning_ra.shtml>.

[25] Russian Military Analysis: Russian Navy: Submarines: SSN [online]. c1997-2008 [cit. 200805-29]. Dostupný z WWW: <http://www.warfare.ru/?lang=\&catid=306\&cattitle=SSN>.

[26] SOKOV, Nikolaj. Update: Russia's Recent Test of New Submarine-launched Missile Succeeds. WMD Insights [online]. 2007, no. September [cit. 2008-05-29]. Dostupný z WWW: <http://wmdinsights.com/I18/I18_R3_Update-BulavaTest.htm>.

[27] ŠVESTKA, Jaroslav. Vojenská a politická reakce Evropy a Ruska na BMDS Spojených států amerických.. Diplomová práce [online]. 2008 [cit. 2008-05-29]. Dostupný z WWW: <http://www.is.muni.cz/th/65339/fss_m_b1/>.

[28] WOOLF, Amy. U.S. Strategic Nuclear Forces: Background, Developments, and Issues. Congressional Research Service Reports [online]. 2007 [cit. 2008-05-29]. Dostupný z WWW: 〈http://www.fas.org/sgp/crs/nuke/RL33640.pdf>.

\section{POUŽITÉ ZKRATKY}

$\begin{array}{ll}\text { ALCM } & \text { - air-launched cruise missile; letecká střela s plochou dráhou letu } \\ \text { C3 } & \text { - command, control, communications; systém velení, řízení a komunikace } \\ \text { CEP } & \text { - circular error probable; poloměr kruhu do něhož dopadne nejméně polovina } \\ & \text { hlavic } \\ \text { EMP } & \text { - elektromagnetický puls } \\ \text { ICBM } & \text { - intercontinental ballistic missile; mezikontinentální balistická raketa } \\ \text { MAD } & \text { - mutual assured destruction; vzájemné zaručené zničení } \\ \text { SLBM } & \text { - submarine-launched ballistic missile; balistická raketa odpalovaná z ponorky } \\ \text { SSBN } & \text { - ballistic missile submarine, nuclear-powered; reaktorem poháněná ponorka s } \\ & \quad \text { balistickými raketami } \\ \text { SSK } & \text { - hunter-killer submarine; konvenčně poháněná útočná ponorka } \\ \text { SSN } & \text { - attack submarine, nuclear-powered; reaktorem poháněná útočná ponorka }\end{array}$

